\title{
SOCIAL ASPECTS OF REVITALIZATION OF URBAN PUBLIC SPACES
}

\author{
MARTA SZAJA \\ University of Szczecin, Faculty of Management and Economics of Services, POLAND \\ e-mail: marta.szaja@wzieu.pl
}

\begin{abstract}
\begin{tabular}{l|l} 
RECEIVED & 10 December 2018
\end{tabular}
ACCEPTED 28 December 2018

JEL

CLASSIFICATION

$\mathrm{R} 11, \mathrm{R} 51, \mathrm{R} 58$

KEYWORDS revitalization, urban spaces, local communities, social participation

ABSTRACT The main goal of the paper is to present the significance of social participation in management of the revitalization process of urban public spaces. On the basis of the available literature the paper discusses social challenges that local authorities face when trying to resuscitate degraded areas. The following research methods were used for the purpose of this paper: desk research, an analysis of the Polish and foreign literature on the subject as well as an analysis of the Polish legal acts regulating the procedures related to the subject of research and the methods of economic analysis. One of the final conclusions stated that local authorities usually pin their expectations on positive results of revitalization activities, but unfortunately not all attempts of restoration of degraded public urban areas bring the desired results. It happens that even numerous efforts to regain the urban degraded tissue do not lead to the expected level of economic, social or cultural revival.
\end{abstract}

\section{Introduction}

In city management, it is undoubtedly important to be able to use its potential by local authorities and overcome development barriers. For this purpose, it is important to develop integrated, perspective and multidimensional plans (Czermiński et al., 2001, p. 151), adjusting the concept of development to anticipated, changing situations that create market and environment conditions (Penc, 2002, p. 125), unique distribution of resources giving the city a unique 
character (Gawroński, 2010, p. 34), and what is particularly important - including in this process various areas of social life, integrating local community, not only to approve the initiatives, but also actively participate in them.

One of the essential tools for city development, which undoubtedly forms the basis for the growth of its competitiveness and prevents the marginalization of some areas (Potoczek, Stępień, 2008, p. 54), is the process of revitalization (renewal) of degraded city tissue. It stimulates long-term economic development, further reducing chaos in the urban space, building a sense of local identity and strengthening social ties.

Local community representatives exhibit a different level of activity and involvement in city management, management of its financial and material assets, or transformation of the functional and spatial structure. Nevertheless, increase in the social awareness of the potential and right to influence the surrounding reality, in the number of entities participating in public life or in the number of opinions regarding the process of transforming space are becoming more and more visible. The aim of this study is to present the significance of social participation in management of the revitalization process of urban public spaces.

\section{The essence of the revitalization process}

In the light of binding provisions of the Act on Revitalization - revitalization denotes the process of recovering from the critical state of degraded areas, which is conducted in a comprehensive way by integrating the activities for the benefit of the local community, space and economy (Art. 2.1 Ustawy z dnia 9 października 2015 r. o rewitalizacji).

Revitalization is a term that mainly concerns a comprehensive process of regenerating an urban area, the space, functions and substance of which have been structurally devastated leading to a critical condition which renders impossible or hinders proper economic and social development of this particular area as well as sustainable development of the whole city (Belniak, 2009, p. 50; Szaja, 2016, pp. 169-173). Revitalization projects should not only be a tool for rehabilitation, but also a source of increase in the urban resources and infrastructure as well as provide an impetus for the optimization of using these.

Each urban system is characterised by a dualistic socio-spatial structure. Within the framework of the social subsystem a social level and an economic level can be distinguished. The urban subsystem encompasses urban substance and the natural environment. There is a fifth level as well, which concerns identity and image. One of the key elements of a successful regeneration of the public space is to understand how significant these levels of revitalization are and how they interrelate. In order to bring the expected results, the rehabilitation of degraded urban fabric must be carried out on all the aforementioned levels (Janas, Jarczewski, Wańkowicz, 2010, p. 117) (see Figure 1).

Among the entities involved in the revitalization process, three basic groups can be identified (see Figure 2).

Although the process is usually slower after being included in the local community revitalization program, it is carried out more effectively and guarantees a permanent effect. Cooperation with residents and business entities as well as with public, social and economic institutions and also a well-thought-out and prepared revitalization program of degraded city areas causes that the institutional city hosts (i.e. local government) share the risks and costs of the undertaken ventures as well as the benefits resulting from the introduced improvements (Pirveli, 2008, p. 31). 


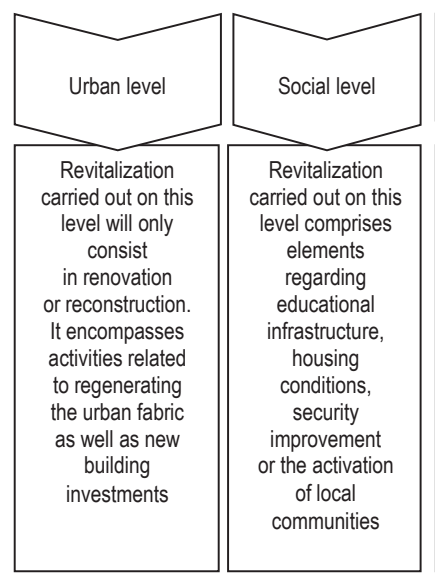

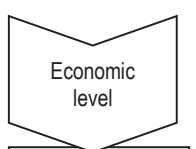

Revitalization encompasses comprehensive economic activation

in the rehabilitated area, creating favourable conditions for conducting economic activity

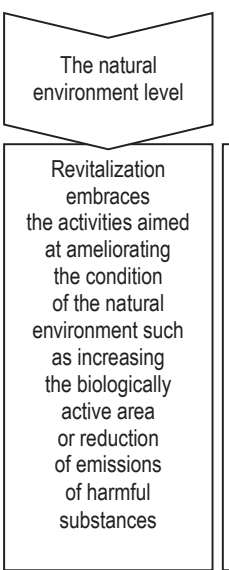

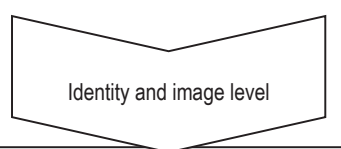

Revitalization comprises the aspects of both social and urban subsystems since identity and image are created by physical elements such as architecture or landscape as well as social elements such as people, traditions, culture. Moreover, the identity of a city has an objective dimension, i.e. particular features of a given place (genius loci - Latin for the guardian spirit of a place) as well as a subjective one which encompasses the identity of city dwellers and their attachment to a given place

Figure 1. Revitalization levels

Source: own compilation on the basis of: Janas, Jarczewski, Wańkowicz (2010), p. 117.

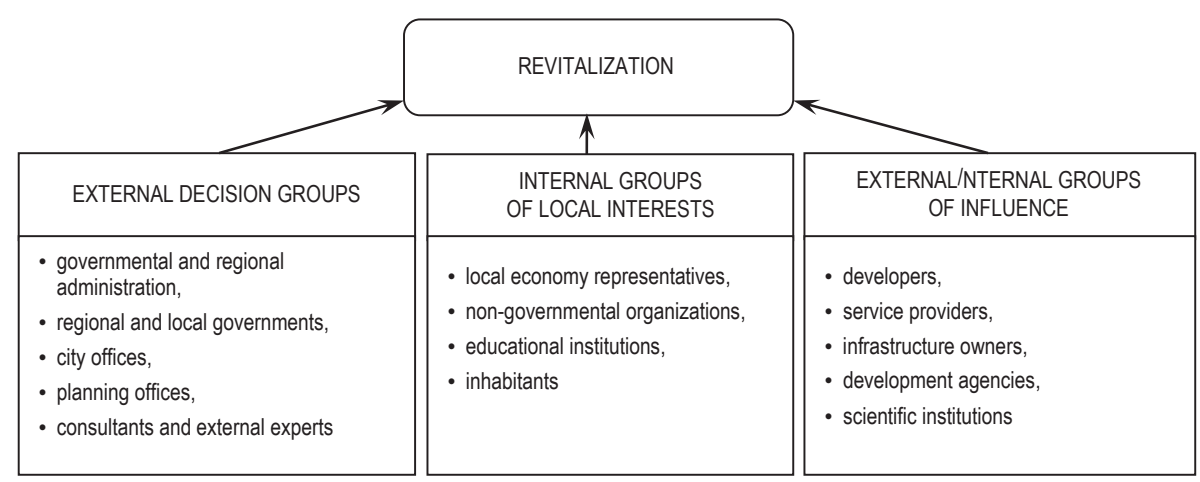

Figure 2. Entities involved in revitalization process

Source: own compilation on the basis of: LUDA-Team (2006), p. 16.

\section{Role of public engagement in the urban revitalization process}

The main among many tasks imposed on local authorities by the legislator is meeting the needs of urban residents. It is implemented, among others, through appropriate local space management, determining (adequate to the existing potential and external conditions) directions of the city's development, creating for local entrepreneurs a wide range of opportunities to undertake economic initiatives, guaranteeing safety on city streets, providing decent living conditions, providing housing conditions for current and future residents, checking the compliance of implemented projects with the sustainable development goals, etc. All initiatives implemented in the city are 
primarily aimed at providing local stakeholders ${ }^{1}$ with levels of agreement and cooperation to undertake activities conducive to achieving a specific level of development and economic profile of the individual.

Currently, local self-governments, in order to achieve the main goal (i.e. to initiate and coordinate broadly understood development), must look for new opportunities and create new localization qualities that can be achieved by qualitative development. It is located, among others through discovering historical and cultural values, restructuring of areas abandoned by industry, army and railways, renewal of old construction resources, qualitative development of centers and intelligent distribution of areas for modern technology, management, consumption, culture and science. In this way, urban development tasks become first of all tasks of a qualitative renewal of existing material resources and at the same time a renewal of human resources (Bielniak, 2009, p. 49).

The main aspects of city development include:

- improving the quality of living environment for residents,

- improving the quality of the socio-economic space (including through revitalization activities),

- creating jobs and a favorable economic climate,

- achieving economic stability and immunity to external disturbances,

- creating convenient settlement conditions for those seeking better living conditions.

It is in the interest of local self-government to create such opportunities that will attract activities that contribute to the implementation of the plans previously set, and additionally, their implementation, apart from individual benefits, will achieve the desired (maximum) local effect (Meyer, 2008, p. 160).

The desired local effect for any city is to achieve order in its most important areas of functioning: social, economic, spatial and ecological. Any changes introduced by means of individual tools that affect elements of the system should be expected (or at least accepted) socially, economically justified and environmentally acceptable (guaranteeing sustainable development of the city).

The fundamental values for the revitalization and development of urban public space are local communities, and in particular the mutual trust of these entities. The condition for building trust, and at the same time manifesting its presence, is the high quality of communication as well as clarity and transparency of activities. The space revitalization process is thus expressed in the emergence and development of social relations that characterize (Smagacz, 2008, pp. 11-12):

a) increase in trust between individual and collective entities (residents, users, institutions); participants are becoming more and more open, more and more willing to undertake new tasks and challenges, carry out reflection criticism (e.g. personal criticism is replaced by substantive criticism);

b) deepening cooperation - the emergence of new contacts between entities and the external environment; during the interaction, during interaction, groups are created to initiate new activities and solve specific problems;

c) increase in activity; the accumulation of knowledge and results of actions drives further actions - new ideas appear, the number and diversity of tasks increases as well as the efficiency of activities;

\footnotetext{
${ }^{1}$ These are various interest groups, pursuing their own, not only economic goals, e.g. local residents, entrepreneurs, local government activists, politicians, employers, workers, hoteliers, parents of school-age children, etc.; often these entities are guided in their behavior by various motives, goals, ways of obtaining tangible results, as well as a different strength of action and influence (national authority, self-government authority, economic entities, community, etc.).
} 
d) increasing the conviction of individual and collective entities about their impact on district's life, including the sense of achieving success as a success of the local community;

e) reaching a point of no return, that is, a level of participation from which there is no return, because this quality becomes a new culture of social life.

\section{Community participation in the urban revitalization process}

Being active in formulating, making decisions and implementing local politics by representatives of local communities is referred to as participation. In this way, residents try to influence decisions ultimately made by people with democratic legitimacy (Parry, Moyser, Day, 1992, p. 16). In practice, participation requires activity of both people, entities, organizations focused around some common interest (venture), as well as activities of groups organized on the basis of their common place of residence or activities of individuals who are representatives of these groups. The notion of community participation is therefore connected with the concept of representation (Swianiewicz, Klimska, Mielczarek, 2004, pp. 15-42).

An active society is one that primarily demonstrates commitment to the planning and implementation of development policy in the city. The participation of the local community involves the participation of two types of participants and can have a horizontal dimension (social participation) or community (vertical/civic/public participation) (Swianiewicz, Klimska, Mielczarek, 2004, p. 35):

- residents and their organizations (including participation of individual citizens as well as the presence in the politics of local civil society organizations),

- influential actors of social life (e.g. entrepreneurs and their organizations).

An expression of the local community's links with the city are activities undertaken for its benefit. They express themselves in various types of activities of local communities - undertaken consciously and voluntarily, general and targeted. Increasingly, forms of local communities participation are an integral part of city's promotion, contribute to its development in the social, economic, environmental and spatial sphere. One of such activities is an active participation of the local community in the process of spatial and functional transformation of the city, including the renewal of its degraded areas.

The range of opportunities for participation of local community in the revitalization process covers a wide range of activities: from information for residents, through leaflets and surveys, to permanent forums, whose members can constantly participate in planning and making decisions. The most important forms of participation in urban planning include (Sinning, Scholles, 2001, pp. 361-368):

a) district/municipal/inter-municipal/urban/regional forums, which are a common space for commenting on planning problems, giving local governments advice, asking planning questions;

b) councils, commissions, committees which are one of the most common forms of social participation; the way they are recruited and tasks depends on the laws in force in particular country; their aim is to provide advice without formal binding of local governments with its results;

c) social expertise, planning cells are a model of participation related to a specific problem, e.g. people affected by a given category of problem and/or those interested in solving it are organized together with experts (professionals) in one organizational unit; participants develop solutions proposals based on acquired knowledge and experience; results in the form of so-called social surveys are finally published and made available to the public; 
d) plenipotentiaries for urban planning are trained planners appearing as residents' advocates in the planning process; their task consist of counselling, mediation and representatives the interests of social groups in municipal, regional and national bodies;

e) committees and social initiatives.

Local community participation in the revitalization process of the degraded urban public area makes it possible to express, and the local authorities to take into account opinions and objections regarding the future of residents and the environment of the revitalization area. It can also make it easier (LUDA-Team, 2006, p. 13):

a) thorough identification and understanding of a number of challenges faced by the revitalization area community;

b) expression by the local community representatives their expectations, postulates, e.g. through participation in information campaigns or participation in meetings regarding the discussion on the assumptions for the revitalization program of selected areas of the city;

c) public expression of the opinion of local actors based on their experience as consumers, entrepreneurs, residents, victims of crime or an unemployed;

d) incorporating various perspectives and opinions of professional and political elites, contributing to a more integrated decision-making process.

The activity of local community can take the form of inspiration and skillfully developed by the local authorities. It can also be an expression of spontaneous initiatives taken by residents regardless of or against the local authorities. One of the example may be an objection to the location of highways, airports, industries polluting the environment, etc. (Gliński, Palska, 1997, p. 365).

\section{Conclusions}

Numerous benefits (social and economic) achieved by the city in the process of proper planning and subsequent implementation of revitalization works, can be a real and strong incentive to operate for other cities that face similar problems with development of urban public spaces. Local authorities should, however, have exceptional attention to the coherence of their actions and control individual stages of the revitalization process in order to be able to fully use the "dormant" city potential.

The main premise of revitalization process of degraded urban public areas is to preserve its continuity, engaging the largest possible and internally diversified group of recipients of the city's offer. Public entity is usually the initiator of revitalization and is usually able to accurately identify the local community expectations and to prepare the necessary cost calculation. Therefore, local decision makers and investors play the most active role in the revitalization process. Nevertheless, the guarantee of effective implementation and stability of the effects of activities undertaken in the city is the local community. It is a mistake, therefore, to limit the role of local actors of social life (i.e. residents, entrepreneurs, their organizations and associations) to the passive observer of the ongoing process. Apart from invoking unrelenting frustration, this may lead to a lack of acceptance of the changes directions in the functional and city's spatial structure. The inclusion of local communities is therefore necessary to ensure their full commitment to the long-term development goals of the territorial unit. The community's conviction that they are the basic beneficiaries of activities undertaken in the city, favors the implementation of the process and, as a consequence, contributes to the shaping of civil society. 


\section{References}

Belniak, S. (2009). Rewitalizacja nieruchomości w procesie odnowy miast. Kraków: Wydawnictwo Uniwersytetu Ekonomicznego.

Czermiński, A., Czerska, M., Nogalski, B., Rutka, R., Apanowicz, J. (2001). Zarządzanie organizacjami. Toruń: Towarzystwo Naukowe Organizacji i Kierowania "Dom Organizatora".

Gawroński, H., (2010). Zarządzanie strategiczne w samorządzie lokalnym. Warszawa: Oficyna a Wolters Kluwer business.

Gliński, P., Palska, H. (1997). Cztery wymiary społecznej aktywności obywatelskiej. In: A. Domański, A. Rychard (eds.), Elementy nowego ładu (p. 365).Warszawa: Wydawnictwo IFiS PAN.

Janas, K., Jarczewski, W., Wańkowicz, W. (2010). Rewitalizacja miast polskich tom 10, Model rewitalizacji miast. Kraków: Instytut Rozwoju Miast.

LUDA-Team (2006). LUDA E-compendium: Handbook E3. A community-based approach to sustainable urban regeneration: the key role of participation and futures workshops. School of the Built Environment, Napier University, Edinburgh and the Futures Academy at Dublin Institute of Technology.

Meyer, B., (2008). Kształtowanie układów przestrzenno-funkcjonalnych przez turystykę. Szczecin: Wydawnictwo Naukowe Uniwersytetu Szczecińskiego.

Parry, G., Moyser, G., Day, N. (1992). Political Participation and Democracy in Britain. Cambridge: Cambridge University Press.

Penc, J., (2002). Strategie zarządzania. Perspektywiczne myślenie i systemowe działanie. Warszawa: Placet.

Pirveli, M. (2008). Rewitalizacja przestrzeni wytworzonej społecznie. In: M. Kowalewski (ed.), Zmieniając miasto - wokół teorii i praktyki rewitalizacji (pp. 26-34). Poznań: Fundacja Twórców Architektury (FTA).

Potoczek, A., Stępień, J. (2008). Podstawy strategii rozwoju lokalnego i regionalnego. Bydgoszcz: Wydawnictwo Uczelniane WSG.

Sinning, H., Scholles, F. (2001). Weitergehende Formen der Partizipation in der Stadtplanung. In: D. Fürst, F. Scholles (eds.), Handbuch Theorien + Methoden der Raum- und Umweltplanung, Dortmunder Vertrieb für Bau- und Planungsliteratur (pp. 361-368). Dortmund: Dortmunder Vertrieb für Bau- und Planungsliteratur.

Smagacz, M. (2008). Rewitalizacja - o tęsknocie za utopią. In: M. Kowalewski (ed.), Zmieniając miasto - wokół teorii i praktyki rewitalizacji (s. 11-12). Poznań: Fundacja Twórców Architektury (FTA).

Swianiewicz, A., Klimska, U., Mielczarek, A. (2004). Nierówne koalicje - liderzy miejscy w poszukiwaniu nowego modelu zarządzania rozwojem. Warszawa: Wydawnictwo Naukowe SCHOLAR.

Szaja, M. (2016). Polityka przestrzenna w procesie kreowania zrównoważonego rozwoju na poziomie lokalnym. Szczecin: Wydawnictwo Naukowe Uniwersytetu Szczecińskiego.

Ustawa z 9.10.2015 o rewitalizacji. Dz.U. 2017, item. 1023 with changes.

Cite this article aS: Szaja,MD. (2018). Social aspects of revitalization of urban public spaces. European Journal of Service Management, 4 (28/2), 463-469. DOI: 10.18276/ejsm.2018.28/2-55. 